\title{
Performance Evaluation and Countermeasure Study of University Technology Transfer in Middle China
}

\author{
Qinghui Wang \\ Xi'an Jiaotong University \\ Xi'an, China
}

\begin{abstract}
As the significant main part of scientific research in China, university has abundant scientific and technological resources. How to transform scientific research achievements into practical productive forces, deal with the contradiction between market demand and university scientific research achievement, and improve the transforming efficiency of scientific research achievement are always the important problems of university technology transfer development. Take the middle area in china as an example, this thesis has discussed present situation of university technology transfer in this region, constructed scientific university technology transfer performance evaluation index system and analyzed the model by factor analytical method. The results show that the integral level of university technology transfer in middle China is low. The university technology transfer developments are not balanced in different regions. Anhui ranks the first in middle China due to its greatest comprehensive strength. Hubei ranks the second because of its lower score of scientific research output factor. Hunan ranks the third due to its lower score of scientific research input factor. Henan, Jiangxi and Shanxi are the least developed regions in middle China.
\end{abstract}

Keywords - university technology transfer; index system; factor analytical method

\section{INTRODUCTION}

Technology transfer, which means transform the scientific research achievement into actual economic benefits, is the key factor of promoting social and economic development and improving the international competitiveness. As the important guider and pioneer of scientific research development, university has become the indispensable important subject of technology transfer due to its rich talent resource and good technical support. Thus, scientific and effective evaluation index system can help the relevant departments to grasp and analyze the information of scientific research ability level, scientific research achievement quality, technology transfer performance and so on. On the one hand, it can provide reasonable guide and important support for the innovation of university scientific research management system, the improvement of university technology transfer's present situation, the increase of enterprise's technology level, the enhancement of university-enterprise cooperation, the perfection of relevant policy and the construction of intermediary system. On the other hand, it can promote the industry-university-research cooperation, improve the efficiency of scientific research achievement transfer, promote the construction of technology transfer and provide the effective data support and scientific basis for the relevant departments to make decisions [1].

\section{The PRESENT Situation OF UniVERSity TEChNOLOGY TRANSFER IN MIDDLE CHINA}

\section{A. Scientific Research Ability Has Obvious Enhancement}

1) Scientific research inputs are increasing: In 2014, there are a total of 284 universities in middle China. The construction of university provides important hatch platform for the training of high-quality and professional talents. The new breakthrough of university scientific research team construction has achieved, and the scale of talent has expanded further. The number of teaching and scientific research personnel is 188655 , the number of $R \& D$ personnel is 62566 , and the number of R\&D results application and technology service personnel is 7715. The science and education advantages of universities are prominent. While the number of $R \& D$ organization is 1241 , the number of science and technology project is 51215, including 20302 basic research projects, 24723 applied basic research projects and 6190 test development research projects. The environment of scientific research has greatly improved and has provided stable foundation and technical support for the smooth running of technology transfer. The understanding of the importance and necessity of university technology transfer becomes much more profound. The capitals like university self-raised funds and government grant have increased year by year. The science and technology expenditure increased from 11.493097 billion yuan in 2010 to 19.212903 billion yuan in 2014, the annual average growth rate of which is $13.7 \%$.

2) International cooperation has further enhanced: As the growing of comprehensive strength in middle China, the international academic communication and cooperation within this region have increased markedly and laid a solid foundation for the further studying of the foreign advanced technology and the successful experience. Thus, improving its scientific research ability and technology level and strengthen the international competitiveness and social influence. Except for the numerical fall in 2013, the number of international academic conference papers show an upward trend, which increase from 16237 in 2011 to 17178 in 2014 ? In the 
meanwhile, the number of international academic conference attendees increases from 18581 in 2011 to 24801 in 2014 which shows an obvious uptrend. The ability of middle China to organize international activities has constantly improved. There are a total of 341 international academic conferences in 2014, while Hubei, Hunan and Anhui are the regions that held most of the conferences. In addition, the universities located in middle China dispatched 8803 person and accepted 6620 person through international science and technology cooperation in 2014. The international cooperation and communication have become more frequent and broadened the horizon of university scientific research and technology transfer.

\section{B. The Quality of University Technology Transfer Needs Improvement}

1) The scientific research achievements can't meet the market demand: On account of the long-term research concept and thinking mode of universities that focus on theory instead of practice, the technology supply can't meet the demand of market. As the contradiction between scientific research achievement and market demand, lots of scientific research achievements are idle, while the existing system of professional title appraisal is rigid. The attention paid to technology transfer is insufficient, the investment of university scientific research is less, the intermediary service system and organization are immature, the information transfer is lack of timeliness and the cooperation between university and enterprise is less and narrow. The feasibility of scientific research achievement industrialization hasn't been tested reasonably. The market survey is not sufficient because of the insufficient construction of middle-test site. The success rate and economic benefit of scientific research achievement's mass production are low, while the scientific research achievements are lack of pertinence and adaptability, and the technology transfer efficiency is low[2].

2) Relevant policy and system are still imperfect: On the one hand, the lack of relevant policy and system are adverse to the development of university technology transfer. The running of each step is short of legal basis and policy guidance, and the duty of each subject and the distribution of property are ambiguous. In the meanwhile, the intellectual property right protection policy is still imperfect and the benefits of scientific researcher aren't protected enough which reduces the enthusiasm of research [3]. On the other hand, the quality and price of scientific research achievement are difficult to evaluate due to the shortage of scientific research achievement evaluation system. It's not easy for contracting parties to reach the agreement and the evaluation standards which focus on quantity instead of quality have curbed the development of university technology transfer.

\section{UNIVERSITY TECHNOLOGY TRANSFER PERFORMANCE EVALUATION}

\section{A. The Construction of Index System}

Based on the objectivity and the validity of indexes, the university technology transfer performance evaluation index system is built including three indexes: the index of university scientific research input, the index of university scientific research environment and the index of university scientific research output.

1) The index of university scientific research input: Scientific research input is the key factor and the important foundation which affects the scientific research achievement. While the scientific research achievement is the basic premise and the significant guarantee which affects the technology transfer performance [4]. This thesis chooses science and technology expenditure and the quantity of teaching and scientific research personnel as the symbol, and analyzes the relevant content about scientific research input in the two aspects, namely capital and manpower.

2) The index of university scientific research environment: The favorable scientific research environment can contribute to the improvement of science level and the enhancement of scientific research ability. Meanwhile, it's the key to promote the scientific achievement quality and can help transforming it into practical productive force [5]. This thesis chooses the quantity of R\&D organization and the quantity of science and technology project as the indexed to quantify the university scientific research environment.

3) The index of university scientific research output: The level of university technology transfer performance is not only decided by the scientific research input and the scientific research ability, but also the quality of scientific research output. High-quality scientific research achievement can meet the demand of enterprise's production and realize the development of commercialization and industrialization [6]. Therefore, this thesis chooses the quantity of granted patent approval, the quantity of awarded research product, the quantity of technology transfer contract and the actual income of technology transfer in the same year as the indexes to represent the university scientific research output.

Based on the above analysis, the university technology transfer performance evaluation index system in middle China is shown in "Table I". 
TABLE I. UNIVERSITY TECHNOLOGY TRANSFER PERFORMANCE EvaluATION INDEX SYSTEM IN MIDDLE CHINA

\begin{tabular}{|l|l|l|l|}
\hline $\begin{array}{l}\text { first class } \\
\text { index }\end{array}$ & $\begin{array}{l}\text { second } \\
\text { class index }\end{array}$ & \multicolumn{1}{|c|}{ third class index } & unit \\
\hline \multirow{4}{*}{$\begin{array}{l}\text { university } \\
\text { scientific } \\
\text { research } \\
\text { input }\end{array}$} & $\begin{array}{l}\text { science and technology } \\
\text { expenditure }\end{array}$ & $\begin{array}{l}\text { thousand } \\
\text { the quantity of teaching and } \\
\text { scientific research personnel }\end{array}$ & person \\
\cline { 2 - 5 } $\begin{array}{l}\text { university } \\
\text { technolog } \\
\text { y transfer } \\
\text { performan } \\
\text { ce }\end{array}$ & $\begin{array}{l}\text { scientific } \\
\text { research } \\
\text { environment }\end{array}$ & $\begin{array}{l}\text { the quantity of science and } \\
\text { technology project }\end{array}$ & piece \\
\cline { 2 - 5 } & university & $\begin{array}{l}\text { the quantity of Granted patent } \\
\text { approval }\end{array}$ & piece \\
\cline { 3 - 5 } & $\begin{array}{l}\text { scientific } \\
\text { research } \\
\text { produantity of awarded research }\end{array}$ & $\begin{array}{l}\text { the quantity of technology transfer } \\
\text { contract }\end{array}$ & piece \\
\cline { 3 - 5 } & output & $\begin{array}{l}\text { actual income of technology } \\
\text { transfer in the same year }\end{array}$ & $\begin{array}{l}\text { thousand } \\
\text { yuan }\end{array}$ \\
\hline
\end{tabular}

\section{B. Evaluation Method and Data Source}

In order to solve the problems of the excessive number of indexes and the redundancy of index information, this thesis analyzes the university technology transfer performance in middle China by using factor analytical method. By weighing and analyzing its cor-relativity and inherent rule, indexes are reasonably classified. Due to the extraction of common factors, the structure of index system is optimized, the process of performance evaluation is simplified, the model error is minimized and the weightiness of each index is scientifically determined to ensure the scientificity, rationality, reliability and validity of the research result [7]. Based on the operational feasibility and data availability, these theses chooses Anhui, Hubei, Hunan, Henan, Jiangxi and Shanxi as the study objects and conduct the scientific evaluation of university technology transfer performance in middle China. The data is derived from University science and technology statistical data collection in 2014.

\section{Evaluation Result}

Relevant index data is organized and analyzed by SPSS. The output results show that both the KMO test and Bartlett globular test have reached effective standard which means that this group data can be analyzed by factor analytical method. Factor analysis identifies 2 principal components which can be used to explain $96.32 \%$ of the total variance and the initial data information is kept intact. From the rotating component matrix, the first common factor which named "scientific research ability factor" mainly explains the indexes of science and technology expenditure, the quantity of teaching and scientific research personnel, the quantity of $R \& D$ organization, the quantity of granted patent approval and the quantity of awarded research product, while the second common factor which named "scientific research output factor" mainly explains the indexes of the quantity of science and technology project, the quantity of technology transfer contract and actual income of technology transfer in the same year.

In the aspect of scientific research ability factor ranking, Hubei ranks the first in middle China through overwhelming force. As the significant strategic fulcrum in middle China, the university resources in Hubei are abundant, the talent advantage of which is prominent. Besides, the scientific research basis and ability is both the top in middle China. Except for Hubei, the score of the remaining five provinces are all negative, which means that enough attention has not been paid on university scientific research in those regions. Within these five regions, the capital input is less; the government policies are short of guidance and can't meet the needs of university technology transfer. As for the aspects of university development, scientific research training, R\&D organization construction and international communication and cooperation are all needed to be further promoted. And it is the same to the integral scientific research ability and technological level.

In the aspect of scientific research output factor ranking, Anhui ranks the first. Compared with the other five provinces, Anhui has the greatest advantages in this aspect. Hunan ranks the second while Henan ranks the third. The integral technology transfer effect in middle China is not satisfied and the scientific research achievements haven't transformed into practical productive force yet. Hubei, as the leading region in middle region and the important technological province in China, ranks the last. The main reason is that although all the scores of scientific research output indexes of Hubei are higher than the other provinces, the scientific achievements benefits of Hubei don't have the same multiple gaps as the other five provinces when taking its vast input into account. What's more the technology transfer efficiency is low, and the relevant government policies are not implemented. Meanwhile, research direction and achievements of university can't meet the market demands. Plenty of scientific achievements are idle, and scientific education advantages haven't been utilized effectively. Additionally, the function of strategic fulcrum is far from be sufficiently exerted. It is urgent to speed up the construction of Hubei technology transfer, and improve the quality of university technology transfer. The cooperation between universities and enterprises in Hubei should be further enhanced. And actions should be made to accelerate the transformation of university scientific research achievement into practical economic benefits.

In general, Anhui has significant advantages in both the scientific research ability and scientific research output. All the index scores are at the forefront in middle China. Its university technology transfer performance ranks the first among six provinces. The university scientific research ability and research input of Hubei are the best among middle regions. However, its technology transfer efficiency doesn't reach the expected standard. Thus, Hubei ranks the second in middle China. The scientific research output benefit of Hunan is well, but it's short of scientific research ability thus ranking the third. Therefore, it is important for Hunan to change the idea of university scientific research, strengthen the government support, increase the input of university scientific research capital, promote the R\&D organization construction, raise the level of university technology and expand the scale of university scientific achievements. Thus, it can improve its university technology transfer performance fundamentally. Henan, Jiangxi and Shanxi, which are the last three regions, need urgent improvements of scientific research input and achievement transfer. Particularly, each index of Jiangxi and Shanxi are at the bottom of middle China and there is a great 
gap between other provinces. The integral level of university technology transfer in middle China is not satisfied and the university technology transfer development is not balanced in different regions. Thus, the promotion of technology transfer construction and the improvement of the university technology transfer efficiency are still having a long way to go.

\section{CONCLUSION}

\section{A. Build up and Perfect Relevant Policies and Regulations}

By building up and perfecting relevant policies and regulations, the favorable technology transfer atmosphere and legal environment can be built up. The duties of the government are to make great efforts to realize the standardizations and legalization of university technology transfer, bring government's functions into full play, guide the communication among university, enterprise and intermediary organization and effectually improve the university technology transfer efficiency.

Make appropriate preferential policy. Strong support is provided for university technology transfer by the methods of fiscal subsidy, tax privilege and so on. In order to accelerate the pace of scientific research achievement transfer, the government should make appropriate awarding policy. As a result, the enthusiasm of scientific research and the achievement transfer efficiency will be increased since the the scientific research achievement quality and transfer benefit will be better due to this policy. As for Jiangxi and Shanxi, which have less scientific research input, poor scientific research ability and lower transfer efficiency, more attention should be paid by the government. To be more specific, the government grants should be increased, the "green channel" should be opened, the process of university technology transfer should be simplified, and the cost of university technology transfer should be reduced. Only by which, the gap with other provinces would be reduced, the university technology transfer level of various regions in middle China would be balanced. Thus, it should solve the problem of uneven development [8].

Make impeccable intellectual property right protection policy. On the basis of current laws, impeccable intellectual property right protection policy is made to protect the lawful rights of researcher and ensure the smooth running of university technology transfer combined with the practical situation of university technology transfer in middle China.

\section{B. Increase the Scientific Research Input}

On the one hand, the scale of scientific research expenditure should be expanded. The input of university scientific research capital is increased by various financing channels such as university self-raised funds, government grant, social donation, financial credit, investment of enterprise or person and special subsidizing funds. It provides stable financial support for university scientific research. On the other hand, in order to increase the input of scientific research manpower, the university should actively explore new path of scientific research talent training, fully utilized its talent advantage and cultivate professional scientific research talents who are high-quality and high-level[9].

\section{Enhance the Cooperation between University and Enterprise}

Enhancing the cooperation and communication between university and enterprise should go through two dimensions, namely depth and breadth. Actions including actively driving the construction and maturity of middle-test site, promoting the effective combination of industry-university-research, realizing the equilibrium between technology supply and market demand and increasing the scientific research achievement transfer efficiency should be carried out [10]. Aiming for increasing the technology transfer enthusiasm of the researcher like professor and specialist, the proportion of scientific research achievement transfer should be increased in the evaluation standard of professional title.

\section{Promote the Construction of Intermediary System}

The university should promote the construction of platform like university science and technology park and university technology transfer center. Meanwhile, the intermediary service systems which match the university technology transfer trait in new period and meet the demand of enterprise's production should be constructed as well. The multilevel and mufti-functional university technology transfer intermediary organization based on its subject characteristic, talent resource and the science and education advantage should be built too. Last but not the least, it's significant to provide university scientific research achievement transfer with efficient technology intermediary service such as technology consulting, market survey, information transfer, technology broker and achievement evaluation.

\section{REFERENCES}

[1] J. Gangtao and Z. Wei, "The Current Situation and Path Analysis of Scitech Achievement Transformation of Universities in Shanxi," Technology and Innovation Management, Vol.35, No.4, pp.313-316, 2014.

[2] Z. Ruichao, Z. Xiekui, L. Weibin, and G. Zhenghua, "Discussion on the Conversion of S\&T Achievements of University," R\&D Management, Vol.22, No.6, pp.133-138, 2010.

[3] R. Jingyan, "An analysis of the Problems and Solutions of University Technology Transfer from the Government' s Point of View in China,' Science and Technology Management Research, No.4, pp.87-90+97, 2011 .

[4] S. Junhong, Y. Xiaoning, L. Gaohong and P. Yuli, “AAppraisal System of Scientific and Technological Achievement Transformation and Methods in Universities in Western China," Technology and Innovation Management, Vol.31, No.4, pp.408-411, 2010.

[5] L. Zezheng and F. Zhenghua, "Talysis on Influencing Factors of Technology Transfer in Local Colleges and Universities," Science Management Research, Vol.28, No.3, pp.26-29, 2010.

[6] W. Xiaomei, B. Lijuan and Y. Wei, "TEvaluation Systems for the Transformation of Scientific and Technological Achievements in Universities of Shanxi Province," Industrial Engineering Journal, Vol.10, No.1, pp.95-98, 2007.

[7] X. Hongping and W. Ping, "The Construction of the Technology Transferring Performance Evaluation System in China' s Universities and Its Empirical Analysis," Contemporary Economic Management, Vol.35, No.8, pp.31-36, 2013.

[8] H. Gang, Z. Xianghong, L. Weiwei and H. Dan, "Local Institutes:A New Exploration of the Transformation Model of S\&T Achievements in Universities,” R\&D Management, Vol.26, No.3, pp.122-128, 2014. 
[9] G. Dongni, "Technology Transfer System of Chinese Universities," Science Research Management, Vol.34, No.6, pp.115-121+160, 2013.

[10] H. Xianmei, F. Ying and S. Jingle, "Research on Countereasures to Stimulate the Conversion of S\&T Achievements of University," R\&D Management, Vol.22, No.6, pp.128-132, 2010. 